\title{
The Influence of Self-Regulated Learning towards Self-Esteem, Self-Efficacy, and Self-Control of Physical Education Students on Table Tennis Learning
}

\author{
Yusuf Hidayat, Dian Budiana*, Andi Suntoda, Burhan Hambali, Cep Ubad Abdullah \\ Departemen Pendidikan Olahraga \\ Fakultas Pendidikan Olahraga dan Kesehatan \\ Universitas Pendidikan Indonesia \\ *dianbudiana@upi.edu
}

\begin{abstract}
This study aims to examine the effect of the SelfRegulated Learning Model (SRL) on self-efficacy, self-esteem, and self-control of students of the Faculty of Sport and Health Education (to be later referred as FPOK), Universitas Pendidikan Indonesia, in learning table tennis games. The study was carried out using the field experiment method, and posttest control group design, where the SRL model was the independent variable (VI) while the self-efficacy, self-esteem, and self-control as the dependent variable (VD). The population in this study were FPOK students, while the sample was 60 elementary school Physical Education Study Program (PJSD) students who contracted table tennis courses. The instrument used to collect data is a scale to measure the significance of the influence of the SRL Model on self-efficacy, self-esteem, and self-control, as well as interviews to confirm the data collected. The results of the study prove that SRL has a significant effect on self-esteem, selfefficacy, and self-control of FPOK UPI students in Multivariate table tennis courses. SRL has a significant effect on FPOK UPI students' self-esteem in learning Table Tennis Games. SRL has a significant effect on FPOK UPI student self-efficacy in learning Table Tennis Games. SRL has a significant effect on the selfcontrol of FPOK UPI students in learning Table Tennis Games. The group given the SRL intervention proved to have a higher and significant effect than the conventional group on the development of self-control, self-efficacy and self-esteem.
\end{abstract}

Keywords-self-regulated learning; self-control; self-efficacy; self-esteem

\section{INTRODUCTION}

Self-Regulated Learning (SRL) is generally closely related to the field of psychology. This is because SRL relates to factors such as motivation, independence, and self-control. At the beginning of its appearance in the 1970s, SRL was often associated with things such as how a person was able to set targets and make strategies to achieve these targets, how to give and receive effective instructions, and how to force (to motivate) to be consistent with what planned. In the context of the classroom, for example, SRL is often related to how the teacher is able to condition the class by considering the mental abilities and social and economic background of students and the standards that apply in the school.

In the field of education, it is often assumed that SRL is right when implemented in higher education. The maturity of cognitive and affective factors from students in higher education is the reason why SRL is considered relevant when applied in higher education. In a study in Iran conducted by Rajabi [1], it was proven that SRL in the field of education is very important. This research even recommends that in this era of globalization, SRL must be the main consideration in preparing the curriculum, because in the constructivism learning approach, people are required to become independent learners who are able to regulate themselves. The learning process has not been focused on the teacher (teacher-centered learning), but will focus on students (student-centered learning)

In addition, a Romanian study proved that SRL is a predictor of Student academic success. This study found that, SRL along with other factors, namely motivation, were predictors of students' academic success [2]. That is, the better the SRL students, the more brilliant academic achievement. Respondents from this study were first year students in Romania. Students who have effective and efficient plans, discipline in learning, and are able to adapt are proven to have higher academic achievement than students who do not have a good SRL.

In Australia, research on SRL is associated with blended courses where learning is carried out online and offline. The study found that 2 nd year students who had SRL and good selfcontrol were proven to have good academic performance [3]. This research is in line with other studies that link SRL with academic performance in universities [4-6].

In physical education, SRL is very important because students and / or students must be able to regulate themselves to recognize human movement. Students / students in physical education must have good cognitive abilities in motor learning [7]. Research related to physical education and SRL agrees that 
SRL is very influential on the ability of students in physical education classes because they thus have a high determination to complete tasks after assignments in physical education $[4,8$ $11]$.

Based on these facts, this study will examine the influence of SRL on self-esteem, self-efficacy, and self-control of elementary school Physical Education Teacher Education (PGPJSD), Faculty of Sports and Health Education, Indonesian Education University in the Table Tennis Game course.

\section{METHOD}

\section{A. Research Site}

This research was conducted for approximately two months, starting from October 23 to December 11 2018. The research was conducted at the FPOK UPI Gymnasium Building and Sport Hall.

\section{B. Research Method}

This study uses an experimental method with the design of pretest-posttest control group design, where Self-Regulated Learning is an independent variable and Self-Esteem, SelfControl, and Self-Efficacy are dependent variables. In this study, SRL was applied to the Table Tennis Learning course. The aim of applying SRL is to examine how SRL can improve these three aspects in Table Tennis learning so students are expected to be able to regulate themselves from the beginning to the end of the lecture.

\section{Research Participants}

The research subjects used in this study were Physical Education Elementary School Education (PGSD) Study Program students who contracted Table Tennis learning courses. Subjects numbered 46 people, consisting of 23 SRL groups and 23 conventional groups with sample selection techniques using Random Sampling (random selection and random assignment).

\section{Data Collection}

The instrument used in the form of a questionnaire containing statements relating to the influence of SRL on Selfesteem, Self-control, and Self-efficacy measured in a scale (likert scale). For example, in a statement about one of the characteristics of self-esteem, students will find a choice of scale 1 to 5 , where 1 (strongly agrees), 2 (disagree), 3 (disagree), 4 (agree), 5 (strongly agree). The entire data will be taken for one semester throughout the Table Tennis Learning course. The data collection period is divided into 2: the beginning of the lecture, and the end of the lecture.

\section{E. Data Analysis}

All data will be analyzed using statistical analysis techniques / methods, namely descriptive statistics (Mean, Standard Deviation) and Manova inferential statistics one path which aims to see the effect of the experimental group on the development of self-control, self-efficacy and self-esteem. The Independent Sample $\mathrm{T}$ Test aims to see the comparison between experimental groups and the control group towards the development of self-control, self-efficacy and self-esteem univariate.

\section{RESULTS AND DISCUSSION}

\section{A. Statistical Description}

TABLE I. STATISTICAL DESCRIPTION

\begin{tabular}{|c|l|c|c|c|}
\hline Variable & Measurement & Mean & Std. Deviation & N \\
\hline \multirow{3}{*}{ Self-control } & Pre Test & 123.08 & 7.37 & 23 \\
\cline { 2 - 5 } & Post Test & 127.78 & 6.80 & 23 \\
\cline { 2 - 5 } & Total & 125.43 & 7.41 & 46 \\
\hline \multirow{3}{*}{ Self Efficacy } & Pre Test & 23.86 & 3.81 & 23 \\
\cline { 2 - 5 } & Post Test & 30.30 & 2.73 & 23 \\
\cline { 2 - 5 } & Total & 27.08 & 4.62 & 46 \\
\hline \multirow{3}{*}{ Self-esteem } & Pre Test & 23.91 & 2.62 & 23 \\
\cline { 2 - 5 } & Post Test & 29.73 & 2.57 & 23 \\
\cline { 2 - 5 } & Total & 26.82 & 3.91 & 46 \\
\hline
\end{tabular}

Based on the results of the descriptive statistical analysis presented in table 1, the mean pretest self-control variable was 123.08 and the standard deviation of 7.37 then the results of the posttest measurements obtained an average value of 127.78 and a standard deviation of 6.80. On the self efficacy variable, the pretest score was 23.86 and the standard deviation of 3.81 , then the results of the posttest measurement obtained an average value of 30.30 and the standard deviation of 2.73 . While the self-esteem variable processed the pretest value of 23.91 and the standard deviation of 2.62 then the results of the posttest measurement obtained an average value of 29.73 and the standard deviation of 2.57 .

\section{B. Assumption Test}

TABLE II. TESTS OF NORMALITY

\begin{tabular}{|l|l|c|c|c|c|c|c|}
\hline \multirow{3}{*}{ Variable } & \multirow{2}{*}{ Measurement } & \multicolumn{3}{|c|}{$\begin{array}{c}\text { Kolmogorov- } \\
\text { Smirnova }\end{array}$} & \multicolumn{3}{c|}{ Shapiro-Wilk } \\
\cline { 3 - 8 } & & Statistic & $\boldsymbol{d f}$ & Sig. & Statistic & $\boldsymbol{d f}$ & Sig. \\
\hline \multirow{2}{*}{ Self-control } & Pre Test & .157 & 23 & .148 & .967 & 23 & .627 \\
\cline { 2 - 8 } & Post Test & .111 & 23 & $.200^{*}$ & .953 & 23 & .334 \\
\hline \multirow{2}{*}{ Self-efficacy } & Pre Test & .096 & 23 & $.200^{*}$ & .968 & 23 & .631 \\
\cline { 2 - 8 } & Post Test & .139 & 23 & $.200^{*}$ & .941 & 23 & .190 \\
\hline \multirow{2}{*}{ Self-esteem } & Pre Test & .158 & 23 & .143 & .945 & 23 & .225 \\
\cline { 2 - 8 } & Post Test & .221 & 23 & .005 & .886 & 23 & .013 \\
\hline
\end{tabular}

a. Lilliefors Significance Correction

Based on the results of the analysts for the normality test presented in table 2, the values of stretched normality were obtained between 0.05 and 0.20 both in the self-control variable, self-efficacy and self-esteem. The results of the analysis prove that the data of all groups can be assumed to be normally distributed, except for the variable self-esteem in posttest measurements. this is evidenced by the acquisition of the value p_value obtained exceeds alpha 0.05 , except for the variable self-esteem in the posttest measurement which is less than alpha 0.05 . 
TABLE III. TEST OF HOMOGENEITY OF VARIANCE

\begin{tabular}{|c|c|c|c|c|c|}
\hline & & $\begin{array}{l}\text { Levene } \\
\text { Statistic }\end{array}$ & df1 & df2 & Sig. \\
\hline \multirow{4}{*}{ Self-control } & Based on Mean & .032 & 1 & 44 & .860 \\
\hline & Based on Median & .004 & 1 & 44 & .950 \\
\hline & $\begin{array}{l}\text { Based on Median and } \\
\text { with adjusted df }\end{array}$ & .004 & 1 & 42.435 & .950 \\
\hline & Based on trimmed mean & .023 & 1 & 44 & .881 \\
\hline \multirow{4}{*}{ Self Efficacy } & Based on Mean & 2.086 & 1 & 44 & .156 \\
\hline & Based on Median & 2.166 & 1 & 44 & .148 \\
\hline & $\begin{array}{l}\text { Based on Median and } \\
\text { with adjusted df }\end{array}$ & 2.166 & 1 & 40.565 & .149 \\
\hline & Based on trimmed mean & 2.068 & 1 & 44 & .157 \\
\hline \multirow{4}{*}{ Self-esteem } & Based on Mean & .016 & 1 & 44 & .899 \\
\hline & Based on Median & .111 & 1 & 44 & .740 \\
\hline & $\begin{array}{l}\text { Based on Median and } \\
\text { with adjusted df }\end{array}$ & .111 & 1 & 43.956 & .740 \\
\hline & Based on trimmed mean & .044 & 1 & 44 & .834 \\
\hline
\end{tabular}

Based on the results of the homogeneity test analyst presented in table 3 , the value of homogeneity ranges from 0.157 to 0.950 . The results of the analysis prove that the data of all groups can come from the same variant (Homogeneous), this is evidenced by the acquisition of the value p_value obtained exceeds alpha 0.05 .

\section{Hypothesis Test}

1) One-way multivariat analysis

TABLE IV. Box's Test OF Equality of COVARIANCE Matricesa

\begin{tabular}{|c|c|}
\hline Box's M & 3,566 \\
\hline F 1 & 0,550 \\
\hline df1 & 6 \\
\hline df2 & 14026,86 \\
\hline Sig. & 0,770 \\
\hline
\end{tabular}

Box test is used to test the assumptions of MANOVA which requires that the covariance matrix of the dependent variable is the same (homogeneous) or not different. In accordance with table 4 above, the box test value is 3.566 with the $F$ test value of 0.550 and not significant at the $p$-value of $0.770 \geq 0.05$. This means that the covariance matrix of the dependent variable is not different (equal) or homogeneous. Then the next analysis will be continued on the multivariate test, the following multivariate test results are presented in table 5 on the next page:

TABle V. Multivariate Tests

\begin{tabular}{|c|c|c|c|c|c|c|c|}
\hline & Effect & Value & $\mathbf{F}$ & Hypothesis df & Error df & Sig. & Partial Eta Squared \\
\hline \multirow{4}{*}{ Intercept } & Pillai's Trace & .998 & $6292.100^{b}$ & 3.00 & 42.00 & .000 & 0.998 \\
\hline & Wilks' Lambda & .002 & $6292.100^{b}$ & 3.00 & 42.00 & .000 & 0.998 \\
\hline & Hotelling's Trace & 449.436 & $6292.100^{b}$ & 3.00 & 42.00 & .000 & 0.998 \\
\hline & Roy's Largest Root & 449.436 & $6292.100^{b}$ & 3.00 & 42.00 & .000 & 0.998 \\
\hline \multirow{3}{*}{ SRL } & Pillai's Trace & .679 & $29.592^{\mathrm{b}}$ & 3.00 & 42.00 & .000 & 0.679 \\
\hline & Wilks' Lambda & .321 & $29.592^{b}$ & 3.00 & 42.00 & .000 & 0.679 \\
\hline & Hotelling's Trace & 2.114 & $29.592^{\mathrm{b}}$ & 3.00 & 42.00 & .000 & 0.679 \\
\hline
\end{tabular}

In accordance with the results of the multivariate test using the Wilks Lambda technique obtained $F$ value of 29.59 and significant at p_value $=0.00<0.05$. This means that SRL has a significant influence on the development of self-control, selfesteem and self-control, with the variability of self-control variables, multivariate self-esteem and self-control can be explained by the SRL variable of $67.9 \%$ which is indicated by the Eta Squared Partial value (PES) of 0.679. This proves that the first research hypothesis is accepted, thus SRL has a significant effect on self-esteem, self-efficacy, and self-control of FPOK UPI students in Multivariate table tennis courses. Furthermore, further analysis followed by testing the test of between subject effects is presented in table 6 as follows.

TABLE VI. TESTS OF BETWEEN-SUBJECTS EFFECTS

\begin{tabular}{|l|l|c|c|c|c|c|c|}
\hline \multicolumn{1}{|c|}{ Source } & Dependent Variable & Type III Sum of Squares & df & Mean Square & F & Sig. & Partial Eta Squared \\
\hline \multirow{4}{*}{ Corrected Model } & Self-control & $253.565^{\mathrm{a}}$ & 1 & 253.565 & 5.031 & .030 & .103 \\
\cline { 2 - 8 } & Self-efficacy & $476.174^{\mathrm{b}}$ & 1 & 476.174 & 43.157 & .000 & .495 \\
\cline { 2 - 8 } & Self-esteem & $390.348^{\mathrm{c}}$ & 1 & 390.348 & 57.585 & .000 & .567 \\
\hline \multirow{3}{*}{ Intercept } & Self-control & 723758.696 & 1 & 723758.696 & 14359.391 & .000 & .997 \\
\cline { 2 - 8 } & Self-efficacy & 33750.348 & 1 & 33750.348 & 3058.871 & .000 & .986 \\
\cline { 2 - 8 } & Self-esteem & 33103.391 & 1 & 33103.391 & 4883.474 & .000 & .991 \\
\hline \multirow{3}{*}{ SRL } & Self-control & $\mathbf{2 5 3 . 5 6 5}$ & $\mathbf{1}$ & $\mathbf{2 5 3 . 5 6 5}$ & $\mathbf{5 . 0 3 1}$ & $\mathbf{. 0 3 0}$ & $\mathbf{. 1 0 3}$ \\
\cline { 2 - 8 } & Self-efficacy & $\mathbf{4 7 6 . 1 7 4}$ & $\mathbf{1}$ & $\mathbf{4 7 6 . 1 7 4}$ & $\mathbf{4 3 . 1 5 7}$ & $\mathbf{. 0 0 0}$ & $\mathbf{. 4 9 5}$ \\
\cline { 2 - 8 } & Self-esteem & $\mathbf{3 9 0 . 3 4 8}$ & $\mathbf{1}$ & $\mathbf{3 9 0 . 3 4 8}$ & $\mathbf{5 7 . 5 8 5}$ & $\mathbf{. 0 0 0}$ & $\mathbf{. 5 6 7}$ \\
\hline \multirow{3}{*}{ Error } & Self-control & 2217.739 & 44 & 50.403 & & & \\
\cline { 2 - 8 } & Self-efficacy & 485.478 & 44 & 11.034 & & & \\
\cline { 2 - 8 } & Self-esteem & 298.261 & 44 & 6.779 & & & \\
\hline \multirow{3}{*}{ Total } & Self-control & 726230.000 & 46 & & & & \\
\cline { 2 - 8 } & Self-efficacy & 34712.000 & 46 & & & & \\
\cline { 2 - 8 } & Self-esteem & 33792.000 & 46 & & & & \\
\end{tabular}


Table VI. Cont.

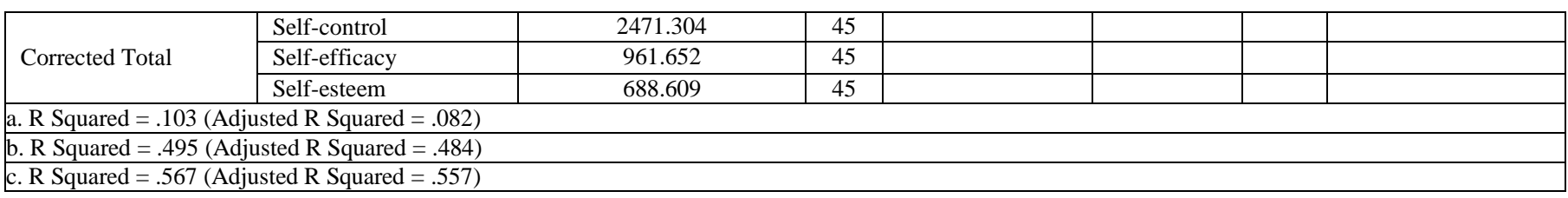

Based on the results of the analysis of the between subject effects tests in table 6 , the $\mathrm{F}$ value for the self-control variable was obtained at 253.565 and significant at $p_{-}$value $=0.030$ $<0.05$. This means that univariate SRL has a significant influence on the development of Self-control, these results prove that the second research hypothesis is accepted, then in testing the self-efficacy variables obtained $F$ value of 43.157 and significant at $\mathrm{p}_{\text {_value }}=0.000<0.05$, this shows that Univariate SRL has a significant influence on the development of Self-Efficacy. The results prove that the third research hypothesis is accepted, in other words, SRL has a significant effect on FPOK UPI students' self-efficacy in learning Table Tennis Games. Then in testing the self-esteem variable obtained $F$ value of 57,585 and significant at $p_{\text {_t }}$ value $=0,000$ $<0,05$. This shows that univariate SRL has a significant influence on the development of Self-esteem, the results prove that the fourth research hypothesis is accepted, in other words SRL significantly influence the self-esteem of FPOK UPI students in learning the Table Tennis Game course.

2) Comparison between experimental and control groups

TABLE VII. INDEPENDENT SAMPLES TEST

\begin{tabular}{|c|c|c|c|c|c|c|c|c|}
\hline & & \multicolumn{2}{|c|}{$\begin{array}{c}\text { Levene's Test for } \\
\text { Equality of Variances }\end{array}$} & \multicolumn{5}{|c|}{ t-test for Equality of Means } \\
\hline & & $F$ & Sig. & $t$ & $d f$ & Sig. (2-tailed) & Mean Difference & Std. Error Difference \\
\hline \multirow{2}{*}{ Self-control } & Equal variances assumed & 3.65 & .06 & 3.71 & 44 & .001 & 11.21 & 3.02 \\
\hline & Equal variances not assumed & & & 3.71 & 37.82 & .001 & 11.21 & 3.01 \\
\hline \multirow{2}{*}{ Self-efficacy } & Equal variances assumed & 1.70 & .19 & 5.96 & 44 & .000 & 7.21 & 1.21 \\
\hline & Equal variances not assumed & & & 5.96 & 41.07 & .000 & 7.21 & 1.21 \\
\hline \multirow{2}{*}{ Self-esteem } & Equal variances assumed & 16.62 & .00 & -33.58 & 44 & .000 & -51.086 & 1.52 \\
\hline & Equal variances not assumed & & & -33.58 & 29.41 & .000 & -51.08 & 1.52 \\
\hline
\end{tabular}

Based on the results of the independent test analysis the sample $t$ test with the aim of testing the comparison between the experimental group and the control group is presented in table 7. the results of the analysis prove that in the self-control variable there are differences between the experimental group and the control group, this is evidenced by the value $\mathrm{t}$ (dk 44) of 3.71 and significant at p_value $=0,000<0.05$, which proves that there are significant differences between experimental group and control group on the development of self-control. Furthermore, the self-efficacy variable obtained a value of $\mathrm{t}(\mathrm{dk}$ 44) of 5.96 and significant at $p_{\text {_value }}=0,000<0.05$, which proved that there were significant differences between the experimental group and the control group on the development of self-efficacy. While the self-esteem variable obtained t value (dk44) of -33.58 and significant at $\mathrm{p}_{-}$value $=0,000<0.05$, it proved that there were significant differences between the experimental group and the control group on the development of self-esteem.

The statistical computation in this study inferred that SRL improves students' self-control, self-efficacy, and self-esteem in learning table tennis. This is in line with a study by Ommundsen stating that self-regulation strategies should be implemented in physical education since students need to have the right decision in such a short time whenever they do physical activity [7]. Moreover, Standage highlighted that selfregulation strategies play an important role in physical education so that students can have good self-determination [12]. Self-determination is also related to self-control, selfesteem, and self-efficacy. In relation to self-efficacy, Bandura argued that it is such an essential skill to master by students so that they will have good cognitive and psychomotor skills [13].

\section{CONCLUSION}

Self-regulated learning needs to be implemented widely in physical education context. This study has proven that it is effective for college students to perform better when they learn. It is recommended that SRL be implemented in elementary and secondary education as well so that learning takes place in the right sequence.

\section{REFERENCES}

[1] S. Rajabi, "Towards Self-Regulated Learning in School Curriculum," Procedia - Social and Behavioral Sciences, vol. 47, pp. 344-350, 2012.

[2] A. Cazan, "Self regulated learning strategies - predictors of academic adjustment" vol. 33, 2012.

[3] Y. Zhu, W. Au, G. Yates, "University students' self-control and selfregulated learning in a blended course," Internet and Higher Education, vol. 30, pp. 54-62, 2016.

[4] L. Mccardle, B.W. Young, J. Baker and L. Mccardle, "Self-regulated learning and expertise development in sport: current status, challenges, and future opportunities current status, challenges, and future opportunities," International Review of Sport and Exercise Psychology, vol. 0, pp. 1-27, 2017.

[5] S. Cassidy, "Self-regulated learning in higher education: Identifying key component processes," Studies in Higher Education, vol. 36 no. 8, pp. 989-1000, 2011. 
[6] Z. Sun, K. Xie and L.H. Anderman, "The role of self-regulated learning in students' success in flipped undergraduate math courses," Internet and Higher Education, vol. 36, pp. 41-53, 2018.

[7] Y. Ommundsen, "Implicit Theories of Ability and Self-regulation Strategies in Physical Education Classes," Educational Psychology, vol. 23, no. 2, pp. 141-157, 2003.

[8] A. Anderson, Learning Strategies in Physical Education, 2013, pp. $37-$ 41.

[9] Y. Hutzler and S. Barak, "Research in Developmental Disabilities Self-e ffi cacy of physical education teachers in including students with cerebral palsy in their classes," Research in Developmental Disabilities, vol. 68, pp. 52-65, 2017.

[10] A. Kolovelonis and M. Goudas, "Learning and Individual Di ff erences The relation of physical self-perceptions of competence, goal orientation, and optimism with students â€TM performance calibration in physical education," Learning and Individual Differences, vol. 61, pp. 77-86, 2018.

[11] K.W.R. Sum, T. Wallhead, S.C.A. Ha and H.P.C. Sit, "Effects of physical education continuing professional development on teachers' physical literacy and self-efficacy and students' learning outcomes," vol. 88 , pp. $1-8,2018$

[12] M. Standage, J.L. Duda and N. Ntoumanis, "A test of self-determination theory in school physical education," British Journal of Educational Psychology, vol. 75, no. 3, pp. 411-433, 2005.

[13] A. Bandura, "COMMENTARY: On the Psychosocial Impact and Mechanisms of Spiritual Modeling," The International Journal for the Psychology of Religion, vol. 13, no. 3, pp. 167-173, 2003. 